\title{
TOURISM ECOLABELS
}

\section{Ralf Buckley}

Griffith University, Australia

Ralf Buckley is Professor of Ecotourism and Director of the International Center for Ecotourism Research at Griffith University (Griffith University, PMB 50 Gold Coast Mail Center QLD 9726, Australia. Email<r.buckley@mailbox.gu.edu.au>) and Director of Nature and Adventure Tourism at the Cooperative Research Centre for Sustainable Tourism. He has worked in tourism since the 80s. His primary research interests are in environmental management in adventure tourism and the contribution of tourism to environmental conservation.

Abstract: Ecolabels in tourism are commonplace but uncoordinated. Established by individual companies, industry associations, voluntary organizations and government agencies, ecolabels range in scale from single villages to worldwide, from single activities to entire destinations; and they include voluntary codes, awards, accreditation and certification schemes. The degree to which they affect consumer purchasing decisions and corporate environmental performance is largely unknown. If ecolabels contribute to informed tourist choice, they could be a valuable environmental management tool, but only if critical conditions are met. Ecolabels need broad coverage and penetration in relevant market sectors, well-defined and transparent entry criteria, independent audit, and penalties for non-compliance. They also need an effective underlying framework of environmental regulation. 
Keywords: accreditation, certification, audit, marketing, association.

\section{INTRODUCTION}

Ecolabels and environmental accreditation are controversial topics in tourism. Tour operators use them in marketing, land management agencies in allocating operating permits, government agencies in promoting national interests, and ecotourism associations for education, lobbying, and revenue generation. While environmental groups endorse some and reject others, all these players hope that individual consumers pay attention.

By far the greatest proliferation of tourism ecolabels is in Europe, and particularly in and around Germany, but there is also a global label first started by the World Travel and Tourism Council. Ecolabels have recently attracted the attention of multilateral tourism and multilateral environmental organizations alike. This paper reviews some of the more significant issues which influence what ecolabels can achieve in tourism and under what circumstances, and whether existing ecolabels are likely to live up to this potential.

\section{ECOLABELS IN PRINCIPLE AND PRACTICE}

A label is simply a description of something, associated with it in some way so that a potential purchaser or user can obtain information from it rather than the object itself. Labels may be spoken or written, text or image, brief or extensive, fixed or detachable, accurate or inaccurate, reliable or misleading, local or global, one-off or systematic. They may contain information only from owners or 
vendors, or from third parties such as independent certification agencies.

In its broadest sense, an ecolabel is simply one whose content refers principally to the environment. For example, it could denote either the state of the natural and/or social environment at a particular time and place, or environmental management or performance measures. If the latter, it may refer either to practices undertaken, or outcomes. As such, ecolabels can include poorly-defined terms applied to particular products or industry sectors, such as green, nature, sustainable ecotourism, etc; environmental awards of various kinds; membership schemes, where participants make a commitment to environmental performance, even if vaguely; and certification and accreditation schemes, where a nominally independent third party assesses companies, operators, guides or products against pre-defined environmental criteria.

While all of the above may be considered ecolabels in the broadest sense, the term has developed a much more specific meaning in other industry sectors, notably in the literature of international trade. It seems likely that ecolabel terminology in tourism will soon fall into line with other industries. If trade terms are applied in tourism, some of the categories listed above would be excluded. An ecolabel in the trade sense is effectively a certification of a particular level of environmental performance in the production of an internationally tradable product (Buckley 1992). That is, it is based on objective criteria and is available to any product which meets them at a particular time, though they may change from one year to another. It is not a competitive ranking system in which the outcome for one particular product depends on the relative performance of other 
products at that time. Therefore, environmental awards though ecolabels in the broadest general sense, are not such in the lexicon of international trade. Similarly, a term such as ecotourism is not an ecolabel in the trade sense, unless it has an internationally recognized definition and has either an accreditation scheme or mutually recognized national standards.

This is far from straightforward, as both countries and large corporations will lobby for definitions that suit their own purposes.

Domestically and internationally, the main function of ecolabels in tourism is as a market mechanism, a component in consumer choice. This applies particularly to those based on environmental certification and accreditation schemes. This is not necessarily the sole function of such schemes. For example, accreditation may also be used as a criterion by regulatory agencies to grant permits; promotion agencies for inclusion in marketing campaigns; and insurance underwriters to issue policies and set premiums. All of these users, however, are likely to have more stringent requirements than retail consumers. Thus, the most basic test of a tourism ecolabel is whether it is accepted by tourists as meaningful, reliable, and useful in choosing individual products.

Context for Effective Ecolabels

The response to any ecolabel by consumers and other stakeholders depends on its social, political, and economic context (Dudley, Eliot and Stotton 1997). Relevant factors include: the particular environmental issue or parameter to which the label refers; the level of knowledge and concern among potential clients and other users in 
relation to environmental issues in general and the ecolabel parameters in particular; the degree of consensus regarding the meaning and significance of terms used in the ecolabel; and the existence, number, and level of acceptance for competing ecolabel schemes.

There is a significant level of environmental concern in developed and developing countries alike, in tourist destinations and countries of origin. This general increase in public environmental awareness, however, may not necessarily translate to a higher response to tourism ecolabels, for various reasons. First, specific environmental concerns and priorities may differ considerably among countries and socioeconomic groups. Second, at a global scale, the level of public concern over the environmental impacts of tourism is far lower than those over such activities as large-scale logging and deforestation. Third, relevant environmental information on competing tourism products may be more difficult to obtain and less clearcut than for retail manufactured products, among others. The last of these, of course, provides one of the principal market functions of an ecolabel. On behalf of consumers who may not individually have sufficient time, resources or perhaps expertise to assess the relative environmental performance of competing products, an ecolabel scheme sets out to define, compile, test, and summarize this information into a readily recognizable and easily comprehensible symbol. This label then simply becomes one of many characteristics a consumer may weigh, according to individual priorities and preferences, when comparing price and features for alternative tourism products.

The processes by which tourists choose which products to buy are themselves part of the context for ecolabels. Do particular individuals, 
or identifiable market segments, choose principally among individual products, individual operators or tour companies, individual agents, or individual destinations? One international tourism ecolabel scheme, Green Globe 21, has recently started to provide environmental certification for entire destinations. This assumes that at least some tourists will choose their principal destination at least partially on environmental management grounds - rather than choosing the destination for its natural or cultural attractions, or personal reasons, and then selecting an ecolabeled tour operator at that destination. Another possibility is that some tourists may choose to travel with a large international tour operator with a good overall reputation for environmental management as well as customer satisfaction; and then opt for a tour and destination offered by that operator.

Assuming that there is sufficient interest among tourists, travel agents and packagers, regulatory bodies, and other stakeholders to persuade individual providers that an ecolabel is worth acquiring, the next contextual issue is what parameters it should incorporate. This involves trade-offs. There is certainly a perception that, for the majority of tourists, a single simple scheme, with a small number of different labels, is needed for customer acceptance. It is argued that a complicated system, or multiple ecolabeling schemes, will generate such confusion that they will all be ignored (Brown et al 1997; Diamantis 1998; Morris, Hastak and Mazis 1995). At the current early stage of tourism ecolabeling, this may well be true. On the other hand, there are also tourists who will pay little attention to an ecolabel unless the details of criteria, evaluation, and audit procedures are made explicit. Other users, such as land managers and other regulatory agencies, are also likely to demand specific details. Thus, a highly simplified ecolabel may not appeal to such users. Parenthetically, 
consumers are routinely expected to differentiate between otherwise highly similar products on a wide range of characteristics, in addition to price and brand. This applies to a very wide range of products, from peanut butter to home finance packages, shorts to shares. As consumers become used to ecolabels, in tourism as in other sectors, they may well demand more detail.

The current market context for tourism ecolabels, therefore, suggests that for maximum market response, a scheme should incorporate four essential components. One, it needs global brand recognition and audit procedures, and customized local implementation. Two, it needs different detailed criteria for various types and scales of tourism accommodation, transport, tours, and activities. Three, it needs at least two levels of labeling, with a broad basic mass-market easilyobtainable label for above-average sustainability or environmental management performance, and a much more detailed, restricted and hard-to-get specialist label restricted to top performers on a range of stringent environmental criteria. Four, it needs transparent criteria and procedures, with detailed information readily available to the public as a backup for the labels themselves.

The social context for ecolabels hence includes not only the broad level of market interest in environmental aspects of the industry, but also the general perception of terms such as sustainable tourism and ecotourism. These terms have been debated extensively (Buckley 1994, 1996; Fennell 1999; Stabler 1997; Swarbrooke 1999; Weaver 1998, 2000; WTO 1998a, 1998b), and the details do not need to be reiterated here. Broadly, sustainable tourism means tourism at any scale with practical and proactive design, engineering, and management to reduce environmental impacts. Nature-based tourism 
is reliant on the natural environment as the principal component of the product, or an essential setting for the operation/activity. Ecotourism, as such a form, is usually small-scale, ideally with a significant environmental education component and some contribution to conservation of the natural and cultural environment.

Although academic debate over the precise definitions of these terms continues (Weaver 1999), most policy documents from governments and industry associations seem to follow the broad distinctions outlined above. There is probably least consensus in relation to the term ecotourism. In Australia, for example, a federal government definition (Commonwealth Department of Tourism 1994) included education and conservation, as well as a nature-based product and sustainable management. In contrast, a state government policy document (Department of Tourism, Small Business and Industry 1997) referred only to sustainably managed tourism in a natural setting. This is another reason why, in a multi-tier ecolabel system, the higher tier needs to be defined with particular care.

The terms "sustainable" and "nature” are barely used in marketing material and other public documents produced by individual tourism corporations. The term ecotourism is used quite widely, but so loosely as to be almost meaningless to the individual consumer. This, of course, is one good argument for ecolabel schemes with independent accreditation. Large-scale developments which advertise themselves as ecotourism tend to generate scrutiny and suspicion. Examples include the proposed Papagayo development in Costa Rica and the recentlyrejected Naturelink development proposal in Australia. Large mainstream corporations and associations tend to use noncontroversial terms such as environmental management which are 
applicable in all sectors (British Airways 1999; IHEI 1997). As a wellestablished term equally applicable in all industry sectors, this would generally not be considered an ecolabel. Such schemes, and other forms of accreditation and quality labeling, need not necessarily be defined in legislation. To the extent that they are used as advertising, however, they may fall within the ambit of trade practices legislation (Grodsky 1993). In Australia, this applies at both federal and state levels.

\section{Evolution of Ecolabel Schemes}

Historically, there seems to have been a common pattern in the evolution of ecolabels and other quality schemes in a wide range of sectors. While not all conform to this pattern, it seems to illustrate a number of social processes which form part of the context for any ecolabel scheme. In the earliest stages, there are several major components in chronological order. One, universities, nongovernment organizations, or private research groups identify an environmental issue as significant. Two, mass media coverage and public debate raises public, industry, and government awareness of the issue. Three, if sufficient consensus and public concern is generated, the issue may reach the agendas of government policymakers and corporate board members. Four, individual companies start to ecolabel products in relation to the issue concerned. Five, other companies follow suit, perceiving a market advantage with no attendant costs. Six, companies commonly charge a premium for ecolabeled products. Seven, individual consumers, followed by watchdog organizations, complain that the label is meaningless and that people are being duped. Eight, legal actions for misleading advertising may be brought under fair trading legislation. Nine, if such actions are brought successfully, the 
next steps are accelerated; but they may also occur without any legal action. Ten, either government or industry or both act to formalize the meaning and use of the ecolabel.

At this point, there are at least two essentially different paths, though the end result may be the same. The first path is that government agencies act to define the meaning of the ecolabel and restrict its use. This may happen in various ways. Broadly, either the government may prohibit particular actions except for individuals or companies which have met legislatively defined procedural and/or substantive criteria, described by means of an ecolabel. Alternatively, the government may simply restrict the use of a particular ecolabel, e.g., by establishing a legislative standard. For example, in many countries there are national standards for ecolabels on manufactured consumer goods. Whether this has any practical outcome will then depend on the market value of the ecolabel concerned. There are also various hybrid approaches (Buckley 1997).

Alternatively, use of the ecolabel may be formalized by a private sector organization, either by coopting an existing term or by establishing a new label related to an existing public concern. Relevant agencies range from the broad, unspecialized and international, such as the International Standards Organization, to more specialized single purpose, national or local ones. There are two main reasons why industry associations or other groups of private companies establish ecolabel schemes. The first is to forestall or delay government intervention, potentially more restrictive. The second is to provide a market advantage for the particular companies which belong to the ecolabel scheme, or those which operate it. 
In either event, where ecolabels and association accreditation programs are established by the industry to which they will apply, initial entrance requirements tend to be relatively lax. This applies to industry-based quality labels of all kinds, in all sectors. There are various reasons for this. If the industry is relatively diverse, such as tourism, and the ecolabel relatively broad, such as "sustainable", then it may be a technically complex task to define substantive criteria which apply across the entire sector, or are appropriately customized to individual subsectors. In such cases, a broad general scheme may be adopted initially, with technical detail added once the scheme becomes established.

A second and associated reason is that the companies or individuals which establish the ecolabel scheme may consider themselves qualified by experience rather than formal examinations. Therefore, they may establish a membership-based scheme where they, as founders, determine whether or not other applicants will be admitted to membership, including the right to use the label. They may establish criteria which are more procedural than substantive. This has the disadvantage of initially creating a clique, but it is commonplace nonetheless, and may be the only practicable option in many instances. The third reason why initial criteria are often lax is a deliberate one. Individual companies are unlikely to devote time, resources, and money to complying with stringent criteria for a new ecolabel scheme whose market value is not yet proven. If companies do not join a new ecolabel, however, it will founder before it can establish consumer recognition. Therefore, industry-based schemes are generally easy to join when first established, in order to maximize initial industry signup. 
Once ecolabel schemes have been in operation long enough for potential clients or the general public to recognize the name, however, there is commonly a demand that the label should mean something, so that customers who pay extra for such products know what they are getting for their money. This may then lead governments to adopt or endorse a scheme originated by the private sector. There are many possible mechanisms (Buckley 1997). As noted earlier, for example, the ecolabel may be embodied in a national standard established by the relevant government authority, for manufactured consumer goods; or it may involve a compulsory professional or corporate registration, certification, or accreditation scheme, for labels which apply to individuals or operating companies.

For an ecolabel scheme to provide something which can continue to satisfy consumers that they receive value for money, it must generally contain two critical components, which might be described as guts and teeth. The guts are the substantive criteria that distinguish between products, professionals, or corporations which have earned that label, and those which have not. For example, these might include specific differences in environmental impacts, management technologies or practices adopted, or skills possessed by an individual tour guide. The teeth of a scheme are the procedures adopted to ensure that the label is only used where it has been earned, and that it is withdrawn if no longer applicable. These include application, assessment and audit procedures, and effective and appropriately enforced penalties for unauthorized use of the ecolabel (Buckley 1999).

Both the guts and teeth of an ecolabel may be provided by the private, the public, or both sectors jointly. It is not clear whether consumers discriminate between schemes on this basis, or even recognize the 
distinction. They are more likely to make an assessment based on how this operates in practice. For example, they may judge products or companies based on personal experience or friends' word-of-mouth in relation to the ecolabel concerned.

One example of an ecolabel which has passed through this evolutionary process is for biodegradable detergents in Australia. Initially, detergents were labeled biodegradable purely as a penaltyfree marketing device, with no fixed or formalized criteria or audit processes. Following consumer complaints, an official Australian standard was constructed so that containers of detergent for retail sale can now bear labels specifying that they are biodegradable as defined in that standard. A detergent which does not meet it can still be marked as biodegradable without reference to the standard. Potentially, however, its manufacturers and distributions might be subject to a lawsuit alleging misleading advertising; and even if they won the case, the risk of losing sales through associated adverse publicity might outweigh the potential revenue gain from labeling the product as biodegradable. Indeed, even without a legislated standard, as in this case, trade-practices actions or other negative reports from consumer or environmental organizations may modify the risk/return ratio for unwarranted use of well-established ecolabels in much the same manner.

Perhaps the end point in the evolution of any quality scheme, ecolabels included, is when they become such a routine part of normal business relations between company and customer, that they lose the connotations of a label and become perceived as an automatic requirement. Unregistered doctors, nurses, or lawyers, for example, are effectively unable to practice in developed countries; but this was not 
always the case, and indeed, currently does not apply in many developing countries. Similarly, in most developed countries a vehicle which is not registered as roadworthy is not permitted on public roads, and processed foods which have not been certified safe for human consumption are not permitted on supermarket shelves.

There are other quality labels which are currently widespread but not yet automatic. Examples include certification in the accounting profession, energy labeling of domestic appliances, and manufacturing labels such as the Woolmark. While tourism ecolabels are in a still earlier stage, other sectors provide indications that they will likely evolve along similar lines. In this context it is interesting to compare two particularly well-known tourism ecolabeling schemes, Green Globe and the Australian National Ecotourism Accreditation Program (NEAP). Green Globe was started by the World Travel and Tourism Council, the peak international tourism industry association. In its initial form it was promoted heavily and gained substantial acceptance and sign-up. It was perceived as lacking in substance, however, and gained little acceptance from consumers, government agencies, the World Tourism Organization, and even associations such as Tourism Council Australia. Without such acceptance, it lost value to its member companies. As a result, it has now been reconstructed as Green Globe 21, separate from WTTC, with plans for more detailed criteria and effective audit.

At first inspection, Australia's National Ecotourism Accreditation Program (NEAP) does not seem to fit the general pattern outlined here. Even in its first operational form, it contained substantive criteria for accreditation. It also contained provisions for audit. Perhaps in consequence, initial uptake was relatively low. NEAP has recently 
been reconstituted as the Nature and Ecotourism Accreditation Program, however, with the addition of a new and easily-achieved "nature tourism” category. The need for a relatively lax entry-level ecolabel, to promote initial acceptance, may hence apply to NEAP as much as to other ecolabelling schemes.

In short, the context for any form of consumer quality labeling, including tourism schemes, includes: the level of interest, knowledge, and concern over the issues addressed by the label among customers, regulators, other stakeholders, and the general public; market demand and willingness to pay or choose between alternative providers for ecolabeled products; and the evolution of procedures and criteria which satisfy customers that the ecolabel is meaningful and reliable, and satisfy providers that the market advantage of ecolabeled products outweigh the costs of obtaining the label.

\section{Effective Ecolabel Schemes}

As with any other form of consumer quality labeling, tourism ecolabel schemes can differ considerably in regard to aspects such as: geographic scale; tourism subsectors covered; environmental issues addressed; restrictiveness and equity of access; product, company or individual focus; membership or external certification format; technical detail and specificity; and level of audit and transparency.

For maximum effectiveness, the label needs to be recognized throughout the target market for the tourism products or companies which use it. Some facilities, such as local bed-and-breakfast establishments, may rely principally on local domestic business. A specialist and restricted ecolabel, recognized only in the local 
geographic region, may be quite adequate in such cases. Other tourism businesses rely principally on clients with very specialized interests, such as golf or birdwatching. The market and the environmental issues may be global, but specialized. Relevant ecolabel schemes need to reflect that specialization; but they need only be recognized by clients and potential clients with sector-specific knowledge and access to it. Similar considerations may apply for operations in particular types of environment, such as coral reefs or polar regions. In such cases the potential clientele may be global and possess a broad range of interests, but the critical environmental issues are specific to the ecosystem, and clients may respond best to an ecolabel scheme which reflects those particular issues.

Increasingly, however, tourism has become an internationally competitive industry which thus needs globally recognizable ecolabels. In addition, several market segments which have high average levels of environmental concern, and are likely to be influenced by ecolabels, also have a high propensity for international travel. Best-known of these are the backpacker segment and the older, relatively well-off specialist ecotourism sector. Arguably, these tourists do not form a single international market, but an overlapping set from different countries of origin, commonly with different languages and levels of cultural and ecological concern. Strictly speaking, although ecolabels need to be applied internationally, they need only be recognizable within individual countries or regions of origin. A good example of such a scheme is that established by TUI, Touristik Union International in Germany. A country-by-country approach, however, would ultimately lead to large numbers of overlapping ecolabel schemes in each destination country, each operated by a different country of origin. While this may be inevitable 
in the early stages of tourism ecolabeling, it would not be an efficient long-term approach.

A single global tourism ecolabel scheme would have significant advantages in recognizability, by tourism companies, customers, and host communities alike. To be effective, however, it would need to be highly customized to different countries, ecosystems, and tourism activities. Customization to ecosystem and tourism activity is needed for the ecolabel to have enough technical detail to improve environmental management and reduce impact of individual tourism operations. Customization to country is needed so that practical implementation can take advantage of different social, cultural, economic, and legal frameworks in different parts of the world, rather than attempting to impose a universal model.

\section{Green Globe 21}

Green Globe was the first and still the only attempt at a single ecolabel scheme applicable to all forms of tourism worldwide (Green Globe 21 2000). It is a membership-based scheme and was initiated by the World Travel and Tourism Council. Technical entry criteria were relatively lax, the scheme was heavily promoted, and industry sign-up was high. In its initial form, however, Green Globe was perceived by government, consumer, and environmental organizations as lacking in technical detail and audit (or guts and teeth). In particular, the World Tourism Organization, the multilateral government counterpart of the WTTC, did not provide particularly enthusiastic endorsement; and some specialist ecotourism groups criticized it quite severely. But, as already noted, this pattern is quite commonplace in the early evolution of quality label schemes. 
Green Globe is currently attempting to advance to the next evolutionary step: to gain acceptance from consumers, governments, and environmental groups without losing its existing acceptance by industry. With this aim in mind it has been reconstituted as Green Globe 21, a separate private organization distinct from the WTTC. Its new promotional literature recognizes joint responsibilities to companies, consumers, and host communities. A fourth responsibility, to conservation, has also been mentioned (Lipman 1999) but is not given equal weighting on current promotional material. This organization has stated its intention to use local legal and cultural frameworks for implementation. As a first step in this direction, it has established three broad geographic regions (the Americas, AfricaEurope, and Asia-Pacific) and has formed partnerships with local organizations concerned with sustainable tourism and development more generally. One particularly interesting link may be with the Green Seal program in the USA (Green Seal 2000), which provides information and assistance in green purchasing programs. Green Seal has recently produced an environmental purchasing guide for hotels, "Greening Your Property," published by the American Hotel and Motel Associations. Green Globe 21 uses straightforward accreditation criteria based on continuous improvement in environmental performance relating to operational aspects such as energy consumption, waste minimization, and more. Customization to ecosystems and tourism activities is expected to be achieved through guidelines and manuals which are adjunct to, rather than formally incorporated in the accreditation criteria; and which need not necessarily be produced by Green Globe 21 itself. Unlike most ecolabel schemes, it does not intend to adopt any baseline threshold criteria for accreditation. This is a significant weakness for consumers 
and regulators. The scheme offers accreditation to entire destinations, such as the island of Jersey, as well as individual companies.

It remains to be seen how successful this approach will be. It seems to have been triggered at least in part by concerns expressed by environmental and ecotourism organizations at tourism-related meetings of the United Nations Commission on Sustainable Development. These groups are likely to remain sceptical until they can observe practical outcomes (Honey and Rome 2000; WWF-UK 2000). Given the advantages of a globally recognizable tourism ecolabel, however, there is a very strong case to make use of Green Globe, which already has international industry recognition and acceptance, rather than attempting to create a new global scheme in competition with Green Globe; particularly since a new scheme would probably have to go through precisely the same early evolution that Green Globe has already experienced.

\section{National Ecotourism Accreditation Program of Australia}

This program had a very different early history from Green Globe (but as noted above, there now appears to be some convergence). From the outset, it was designed specifically for a tourism subsector with a high level of environmental interest, in a country which considers itself a leader in that field. The first practical step towards the establishment of NEAP was taken by the tourism portfolio in the Australian federal government, as part of a package of ecotourism-related initiatives which also included a national strategy document and a small funding program used to subsidize infrastructure and to a lesser degree research. (This entire program can largely be attributed to the efforts of a very small group of far-sighted individuals within that portfolio at 
the time.) The first draft for a national ecotourism accreditation scheme included detailed procedures but little in the way of substantive accreditation criteria. A second and far more substantive draft, compiled by the fledgling Ecotourism Association of Australia, formed the basis of NEAP as actually implemented. The early involvement of this ecotourism association also meant that NEAP was endorsed from the outset by the specialist industry association concerned, as well as the relevant national government portfolio.

NEAP's principal difficulty, in its early stages, was relatively low industry sign-up. There are several likely reasons for this. One, the Ecotourism Association of Australia was not as well known as it is now, and operators may not have been convinced that NEAP would be an effective marketing tool. Two, perhaps relatively few individual products in the nature and adventure tourism sectors were able to qualify for ecotourism accreditation, even though the criteria were pitched at a level quite easy to achieve. Three, at least for a period, there was a perception that the term ecotourism was being abused as a meaningless marketing tool by some operators, so others which had already established a reputation for good environment management performance may have wished to disassociate themselves from this perception. Four, in particular, it seems there were some residual concerns from an earlier attempt at a national directory of Australian ecotour operators, where it was widely perceived that the relative environmental claims made by different operators did not correspond well to their relative environmental performances in practice. Concerted effort by the ecotourism association during NEAP's early years, with support from a number of state government agencies such as the Environment Branch of Tourism Queensland, increased industry sign-up. By early 1999, a major proportion of Australian tourism 
operators conforming to the general perception of ecotourism had one or more products with basic or advanced accreditation under NEAP.

Yet, while valuable in distinguishing those particular products to potential purchasers, NEAP in its initial form still had relatively limited reach within the Australian nature and adventure tourism sector as a whole, and hence relatively little ability to improve its aggregate environmental management, because the vast majority of products in this sector are simply not within the ambit of the scheme at all. Therefore, during 1999 NEAP was revised to include a third level of accreditation, broader and more basic than existing levels (EAA/ATOA 1999). There are now three levels of accreditation: nature tourism, ecotourism, and advanced ecotourism. NEAP has also been renamed, as the Nature and Ecotourism Accreditation Program. There is now also a parallel scheme for accreditation of individual ecotour guides, rather than ecotour products as covered by NEAP. This is known as the National Nature and Ecotour Guide Certification Program. The interactions between NEAP and Green Globe 21 are currently under considerable debate within Australia. The current intention is that NEAP, appropriately customized to different environments and countries, could become the basis for Green Globe 21 accreditation within the specialist ecotourism sector worldwide. This may prove problematic in practice, since NEAP has well-defined substantive criteria, whereas the other is based only on continuous improvement.

\section{Other Tourism Ecolabels}

The report by the United Nation's Environment Program on tourism ecolabels (UNEP 1998) tabulated 28 schemes in 4 categories: 
international, regional, national, and subnational (see also Hamele 1996; Hemmelskamp and Brockmann 1997; Mihalic 1998). The current status of these schemes, derived from internet searches in January 2000, may be summarized as follows. Of the 5 schemes listed in the international category, only Green Globe survives as a largescale ecolabel covering the entire tourism industry. Ecotel, a private label assigned to hotels certified by a private consulting company, still exists but has been applied to only 40 hotels in all, and appears to be largely a promotional device by the consulting company. Another consulting-company label, Ecofriendly Hotels Worldwide, still exists (Buckley 2001) but is apparently not listed on the Worldwide Web under the label or this operator name. The Audubon Cooperative Sanctuary System and the related Audubon Cooperative Sanctuary Program are apparently thriving (National Audubon Society 2000), but apply only incidentally in the tourism sector. Some US mountain resorts are currently negotiating for accreditation (personal communication with Jeff Proteau, head of Environmental Management at Telluride Ski and Golf Co. in 1999).

At the regional scale, one of six schemes is thriving: the European Blue Flag label operated by the Foundation for Environmental Education in Europe (Foundation for Environmental Education in Europe 2000; United Nations Environment Program, 1996). Currently, over 1,800 beaches and over 600 marinas are accredited. Accreditation must be re-earned every year. Criteria are listed on the Blue Flag website. The Green Leaf ecolabel of the Pacific Asia Travel Association (2000) still exists, but its website does not list criteria or accredited products. It is now to be integrated with Green Globe 21. The European Golf Association Ecology Unit (2000), part of a golf industry association, advertises the “Committed to Green” label, 
commenced in 1997. To date, 80 of an estimated 5,200 European golf courses are involved in a pilot program. Accreditation criteria have not been formalized, and the scheme appears somewhat embryonic.

The European Charter for Sustainable Tourism in Protected Areas was funded by the European Union until 1999 (Buckley 2001), but is apparently no longer listed either by European Union (2000) or by its sponsoring organization, the Europarc Federation (2000). It is currently awaiting further funding (personal communication with Xavier Font, Leeds Metropolitan University, in 2000). The "Silver Thistle" ecolabel in Kleinwalser Valley, a destination area on the border between Germany and Austria, has been superseded by the " $\mathrm{Q}$ Plus-Kleinwalsertal” label (Kleinwalser Tourismus 2000). By 2000 the Tyrolean Environmental Seal of Quality (Austria and Italy) had been granted to 229 enterprises, and is currently updating accreditation criteria (personal communication with Xavier Font in 2000).

At a national level, the United Nations Environment Program report listed 11 schemes, of which only three currently appear to be operational. Principal among these is NEAP in Australia (Ecotourism Association of Australia 2000) described in detail above. The Seaside Award in the United Kingdom (Tidy Britain Group 2000) has accredited 260 beaches, and also operates the UK component of the European Blue Flag, with 41 British beaches and 26 marinas accredited in 1997. A Worldwide Fund for Nature ecolabel for rural tourism accommodation in France, Gites Panda, also seems to have been adopted extensively, to judge from listings (Federation des Parcs Naturels Regionaux de France 2000): but the relevant website of World Wide Fund for Nature (2000) does not provide information on criteria. The David Bellamy Conservation Award for environmental 
management by holiday parks in the British Holiday and Home Parks Association (2000) is also fully operational, with 3 levels of accreditation. Parks are assessed by the UK Conservation Foundation (2000), cofunded by Bellamy. There are currently 120 parks with Gold, 108 with Silver, and 26 with Bronze awards. The Austrian Label for Ecotourism, Bundesumweltzeichen, has been operated by a variety of different organizations (personal communication with Xavier Font in 2000); currently it is under the Austrian Consumer Association. It has been awarded to around 100 companies (Buckley 2001).

The German automobile association Allgemeiner Deutscher Automobil-Club e.V. is known internationally, but its website does not refer to its Environmental Squirrel label, Umwelteichho"rnchen. The Green Suitcase label proposed by the German Okologischer Tourismus in Europe has been under development since 1991 but is apparently still not operational. The Irish NASC scheme was funded by the European Union at a development level from 1994-1997, but has not become operational (personal communication with Xavier Font in 2000). Most Danish hotels belong to the national hotel industry association HORE-STA (2000), and 100 businesses have currently met criteria for its Green Key label. The scheme is currently under revision (Buckley 2001). The German hotel association DEHOGA (2000) published an environmental code of conduct which has been quoted in green travel listservers, and has granted permission to around 900 businesses to use its tag, "We are an Environmentally Friendly Business." The Green Leaf label in Thailand is mentioned in the United Nations Environment Program promotional material from a few years ago, but its last-known secretariat address was at the Tourism Authority of Thailand (2000), whose current website makes 
no mention of it. Perhaps it is part of the Pacific Asia Travel Association’s Green Leaf program, now joining Green Globe 21.

A similar pattern seems to apply for the six subnational schemes listed by United Nations Environment Program (1998). The government authority for the Alcudia Region in Spain apparently still operates its award scheme, Distintivo Ecoturistico, but with limited scope. The Balearic Islands Ecotour label is currently not operational (personal communication with Xavier Font in 2000). The local label Oko Grischun for Graubunden in Switzerland is apparently not listed on the Worldwide Web, and nor is its sponsoring nongovernmental organization. The Green Tourism Business Scheme in Scotland (Tourism and Environment Forum 2000) is operated by the Scottish Tourist Board (2000) but is not mentioned on its website. About 200 awards have been made. The Scottish Golf Course Wildlife Initiative is listed but is apparently not an ecolabel.

The UNEP survey was representative rather than comprehensive, and there are several others worth mentioning. The private environmental certification operated by the German Company TUI is of particular note (TUI Group 2000). British Airways now also has an environmental code attached to its internal partnership policy, such as for suppliers to its holiday packages (British Airways 1999); but this is apparently not available to the public. The British Airways Tourism for Tomorrow Awards are well-known, highly coveted, and heavily used in international marketing by the recipients. Strictly, however, that is an award scheme rather than a label. Also of note is the program run by the Caribbean Alliance for Sustainable Tourism (2000). It is run by the Caribbean Hotels Association in Puerto Rico, with 
assistance from the International Hotels Environment Initiative and Green Globe 21.

As noted earlier, many tourism accommodation, transport, and tours providers have corporate environmental management programs in place. Many associations, government agencies, and voluntary groups have also produced environmental guidelines, manuals, and codes of conduct. None of these, however, are ecolabels in the sense of a distinguishing device for consumer choice. Current trends and patterns seems to be as follows. At the international scale, there is the industryled Green Globe 21, and labels run by environmental groups such as The Audubon Society and the Worldwide Fund for Nature. These are likely to remain independent. At national or regional scales there are two thriving schemes with well-developed criteria and procedures and good consumer recognition in their target markets: NEAP in Australia and Blue Flag in Europe. While it would be feasible for these to be integrated into Green Globe 21, this currently seems unlikely until the latter has established equivalent market recognition and reliability. Accreditation under either of these schemes, however, might perhaps be taken as automatic evidence for its equivalent under Green Globe 21. Particular industry sectors, notably golf, have originated a number of specialist schemes which could well be integrated, initially with each other and ultimately with Green Globe 21. Since the golf sector may not view its destiny as lying entirely within tourism, however, this is uncertain. Until Green Globe 21 can demonstrate its credentials, independent company schemes such as that of TUI are likely to remain operational.

Equity and Efficiency of Ecolabels 
Ecolabels are a mechanism for consumer choice. They put the responsibility for improving environmental management in tourism principally in the hands of individual customers. Certainly, it is the tourism providers who actually make the improvements and put ecolabeled products on the market; but they need only do so to the extent that their own particular customers are prepared to pay for such improvements. Governments are involved only at a secondary level, if at all; they may use the ecolabels as an aid in their own decisionmaking, or they may even operate the day-to-day logistics of the ecolabel scheme, but they are not its primary driving force.

This approach has several significant consequences. The first is that where improved environmental management is costly, this money is provided entirely from the post-tax discretionary income of individual people who have a high concern for the environment; extend that concern to their holidays and leisure; and have enough money to pay a price premium. In addition, many or most of these individuals actually live in a different part of the country, or a different part of the world, from the destination area where local tourism impacts are produced. They are paying to reduce their impacts on someone else's local environment.

This raises questions over the equity and efficiency of ecolabeling as a major tool in the environmental management of tourism. Equity issues arise because of the distinction between public and private costs and benefits. Certainly, if it is tourism which is producing a particular environmental impact, it appears equitable that tourism should pay the costs of reducing that impact and restoring the environment. People who buy low-impact ecolabeled tourism products, however, are incurring a private cost shared between a small number of individuals. 
In so doing they generate a public benefit shared among a much larger number of individuals, including themselves and other tourists who buy non-ecolabeled product in the same area, as well as the area's residents and host community.

This is not a pure market mechanism, of an individual choosing to incur a cost to acquire a benefit. The benefit to the buyer of ecolabeled products is diluted. This dilution occurs not simply because noncontributors can still enjoy benefits, which are not reduced for contributors. The dilution occurs because the total improvement in environmental quality is less than it would be if everyone had contributed towards its cost. The more tourists who choose not to buy ecolabeled products, the smaller the benefit gained by those who do. Hence, tourists who choose not to buy such a product are gaining benefit without contributing to its cost. But those who favor this purchase enjoy only part of the benefits they could expect to experience without this dilution factor; with the residual enjoyed by people who have not paid.

Paying a price premium to purchase an ecolabeled product hence requires a measure of altruism. This is a significant barrier. Many are prepared to pay a fair share for a common benefit. This is the origin of the tax system in democratic societies. Few, however, willingly pay more than that share. The endless arguments over the detailed design of tax systems, which are so characteristic of modern democratic societies, provide an excellent demonstration of this principle. In general, therefore, the number of individuals who pay extra for an ecolabeled product, despite the dilution effect, is much smaller than the number of those who would willingly pay for low-impact products if the costs were borne equally by all consumers. Indeed, the high level 
of consumer response to ecolabeled products in the retail sector, despite this factor, is one of the most telling indicators of the strength of environmental concern among the general public in many developed nations.

While ecolabels are a valuable tool for the tourism industry, they will likely be most effective if used along with other environmental management tools, as part of a integrated strategy. Environmental legislation and regulations are also a critical component, because they can provide a base level of protection in an equitable way, with minimal-impact ecolabeled products available as an add-on at a relatively small price differential. This approach is also common in other industry sectors.

\section{Ecolabels and International Trade}

Current interpretations of major international trade agreements generally allow importing nations to distinguish between similar goods, in relation to tariffs or trade restrictions, on the basis of environmental features of the final product. These so-called product standards may include energy consumption, impacts during use, recyclability, and the like. Current interpretations, however, do not permit importing countries to differentiate between products on the basis of environmental aspects of their production process (so-called process standards). These might include the environmental impacts of a mineral production process, by-catch from fisheries, soil degradation from agriculture, or the long term sustainability of logging practices. But such interpretations do permit individual corporations to describe environmental aspects of production processes in product labels, so that individual consumers can take these factors into account in 
purchasing decisions. In international trade, it is these labels — which include environmental certification schemes - which are known as ecolabels. Two well-known examples are labels for dolphin-friendly tuna and sustainably-harvested timber. Ecolabeling remains a controversial topic in international trade, with some stakeholders endeavoring to ban it.

From an international trade perspective, there are some significant differences between tourism and major primary-industry and manufacturing sectors. In the latter, raw materials and processed goods are typically exported from developing to developed countries. The former typically have weaker currencies, cheaper labor, and more lax environmental standards. In essence, they typically argue against improving environmental standards on the grounds that for them, alleviating poverty is more urgent than protecting the environment; and developed countries have already degraded their own natural environments and have no right to prevent them doing likewise. Corporations in developed economies then argue that higher environmental standards, to which their domestic operations are subject, put domestic product at a price disadvantage relative to imported product from developing countries. None of these arguments may be correct; but politically they form a major barrier to the improvement of environmental standards in developed and developing economies alike.

In the tourism industry, however, international exports from developing countries are consumed domestically rather than in developed economies. Outbound tourism operators in the latter have captive markets in the form of their own citizens. They are subject to the environmental laws of that country, but they are not competing for 
the same customers against other countries with different environmental laws. The same is effectively also true for international airlines, since their markets are governed largely by bilateral agreements on reciprocal landing rights. In destinations, all inbound operators, local tourism providers and individual tourists are subject to the environmental laws of that country in the same way as entirely domestic tourism operations. An individual country gains no economic or market advantage by adopting more lax environmental standards than others which are competing for the same tourists, because they are not offering the same product. For manufactured goods, consumers in developed countries have a choice between imported goods from different developing economies, which appear identical once they reach the consumer, with the possible exception of an ecolabel describing environmental aspects of production processes. Those from different countries may have been produced under widely different environmental laws, or using production processes with widely different environmental impacts in the originating country, but to the consumer the products look identical.

In tourism, however, products from different countries are clearly different. For their domestic tourists there is commonly a significant difference in price and convenience between a holiday in their own country, and a corresponding holiday in another. For international tourists choosing between alternative developing-country destinations, each offers a different product. Where different ones offer very similar products, such as beaches and nightlife, or subtropical reef and rainforests, there are still sufficient differences among these countries' cultures and environments for consumers to distinguish their products. In addition, price differences due to airfare differentials, currency exchange rates, and socioeconomic factors in the countries concerned 
far outweigh any possible price differentials which might be associated with differences in environmental legislation. Furthermore, unlike international trade in manufactured goods, in tourism the product is consumed as and where it is produced, so that environmental impacts of production are suffered directly by the consumer and become part of the product package. Government legislation and industry management practices to protect the environment at tourism destinations, therefore, translate directly into better products for the consumer, providing a positive rather than a negative differential from competing products. In the tourism industry, therefore, consumerchoice mechanisms such as ecolabels can operate in a complementary and synergistic way with public-policy mechanisms such as environmental regulations, to a much greater degree than other industry sectors.

\section{Adjuncts to Ecolabels}

The substantive criteria for any ecolabel must include the environmental parameters considered, the ways in which they are to be measured, and the thresholds required to qualify for the ecolabel. For example, ecolabels may be based upon input, in the sense of environmental management effort or measures taken; or on output, in the sense of impact produced. They may be based on qualitative measures, such as the existence of a certified management system, adoption of a particular technology, or avoidance of a particular solvent or pesticide; or they may be based on quantitative measures, such as energy or water consumption, or funding contributed to conservation groups. They may be based on aggregate measures, such as area of land rehabilitated; or on proportional measures, such as per capita energy or water consumption. They may be based on absolute 
measures, such as biological oxygen demand in treated sewage effluent; relative measures, such as the ratio of biological oxygen demand to an industry average, a best-practice benchmark, or the theoretical best-achievable limit; or on differential measures, such as reduction in biological oxygen demand over a defined monitoring period, such as the past year. They may be based on an actual performance measure, such as any of the above; or merely on a commitment to improve performance over a given future period. They may be verifiable, for example by qualified environmental auditors; or they may be so vague as to be effectively meaningless.

A good example of a vague ecolabel, for another industry sector, is provided by statements such as "printed on paper from sustainably managed forests." This is vague because there are enormous differences of opinion as to what constitutes sustainable management for different forest types. For example, it might mean only that logging practices comply with current government requirements, which in most cases are far from sustainable. It might mean simply that the logging company has a replanting program. "For every tree we cut down, we plant another one," say the advertisements, ignoring the impacts of logging on soil and other species, juvenile mortality in the species replanted, and the decades, centuries, or millennia it may take to establish a mature and diverse forest cover. Not surprisingly, therefore, certification schemes such as the Forest Stewardship Council have been established to provide more substantive evaluation of such claims (von Mirbach 1999).

Ecolabels can be not merely vague but downright misleading. During the 90s, a brand of note pad for sale in the United States was prominently labeled “ecology pad”, followed by numerical — and 
hence more convincing - claims of recycled content. It cost about $40 \%$ more than similar pads, despite having fewer pages and lowerquality paper. Printed on the front cover was the claim " $100 \%$ recycled." But this was followed by a qualification: "10\% postconsumer waste"; so $90 \%$ was pre-consumer waste. This is a jargon phrase for residual timber after logging for sawlogs. Where entire coupes or forest sectors are felled for wood pulp, with little or no sawlog production, this may still be referred to as pre-consumer waste. Effectively, "recycled" in this context really meant "made from trees." But worse, even the claim " $10 \%$ post-consumer waste" was misleading. The zero was crossed out with a backslash, so that technically it read only “ $1 \%$ post-consumer waste.” But the backslash was printed in the same style as the zero, not as a later overprint. The deception was deliberate. Hence a product labeled with the eyecatching but meaningless name "ecology pad" and claiming to be $100 \%$ recycled, in fact contained only $1 \%$ recycled material in a generally understood sense.

To be useful in consumer choice, an ecolabel needs to provide reliable identification of products with better environmental management, or lower impacts, than competing but otherwise similar products. An ecolabel is unlikely to be a significant factor in consumer choice, except perhaps for a small group, if hardly any products bear that label; or conversely, if almost all products are ecolabeled. Even the criteria for an ecolabel set as an absolute threshold need to be determined with reference to the range of current performance within the industry. A routine program of environmental benchmarking within the industry sector concerned is thus an important adjunct of any effective ecolabeling scheme. 
This requires companies to report regularly on their environmental management measures and performance. Such corporate reporting though mandated by legislation in some jurisdictions, more commonly is voluntary, either as a condition of joining an ecolabel scheme, or independently as part of the company's marketing strategy. To be reliable, such voluntary corporate environmental reports need to be audited externally, but even then, many auditors' statements are vague and guarded (Vinot 1999). To be reliable, external environmental auditors need to be given the opportunity, and funds, to make independent measurements of parameters referred to in the corporate report under audit.

Guidelines, manuals, and other technical assistance for companies wishing to improve environmental management performance are another important adjunct to schemes. Indeed, some ecolabel schemes, such as Green Globe 21, define their accreditation criteria purely in terms of continuous improvement in major areas such as energy and water consumption, waste management, etc. How that improvement is achieved is up to the individual company to determine, but Green Globe 21 currently plans to publish an extensive series of technical manuals for their members, and prospects' use. The Australian NEAP, in contrast, incorporates a great deal more technical detail within the accreditation criteria themselves. Even NEAP, however, does not attempt to specify individual technologies or management practices, so technical guidelines or manuals are still a valuable accompaniment to the scheme. In addition, the criteria are themselves intended to reflect current best-practice environmental management in the tourism sector, and relevant environmental guidelines are one important technique for disseminating this information to other companies in the industry sector concerned, so that they can apply for accreditation at some 
future date. A range of technical manuals and minimal-impact guidelines are available. These range from relatively broad sector-level documents (UNEP 1995; WTO 1996; Basche 1998; IHEI 1997) to detailed specifications for particular activities (Buckley 2000; NOLS 1997a) or ecosystems (NOLS 1997b).

\section{Evaluation of Ecolabels by Individual Consumers}

It is not always easy for an individual ecotourist to choose between competing products on environmental grounds (Buckley 1995). Without ecolabels, environmentally concerned tourists have to conduct their own research, whether by reviewing brochures and other promotional materials from individual companies, seeking recommendations from friends or travel magazines, or questioning operators directly. But claims in promotional materials are often too vague to be useful; articles in magazines may not always be reliable; and individual companies may not be prepared to answer detailed questions from individual prospective clients, either because they do not think it worth their time financially, or because they see such questions as "troublemaking." Even if information is available, making these comparisons takes a considerable investment of time and effort, which is not what people generally want from their holidays.

Therefore, a reliable ecolabel scheme, is a major boon to would-be ecotourists. Given the current plethora of competing ecolabel schemes in the tourism industry, how can an individual determine which if any to rely on, and precisely what it means? As outlined above, there are many different criteria on which an ecolabel scheme may be judged. To be useful in consumer choice, any ecolabel scheme needs to provide easy public access to its substantive criteria; its application, 
assessment, and audit procedures; and its penalties for noncompliance; as well as the geographic region and industry subsectors covered, and the products accredited to date. One of the major disadvantages of the Australian NEAP in its initial form, for example, was that the substantive criteria for accreditation could only be obtained by purchasing an accreditation application kit, and the price for this kit was set to cover the full administrative costs of processing that application. The individual tourist had no reasonable way to determine what NEAP accreditation actually meant. Similarly, companies considering applying for this accreditation could not find out what criteria they were expected to meet. Criteria used by the German company TUI, in contrast, are publicly available. As an alternative strategy, some individual tourism providers augment or bypass ecolabel schemes by publishing their own environmental codes, which they undertake to follow and ask their clients to comply with. One Australian company, which offers one-to-two-week guided bushwalking tours in remote areas, provides its own environmental code to clients who purchase a tour, with the additional admonition "if you don't have time to read this code, you shouldn't be on one of our tours." Indeed, the company will also provide copies of its environmental code to prospective clients, at a nominal fee which is refunded if the client does purchase a tour.

\section{CONCLUSION}

Ecolabeling in tourism is still in its early stages. As yet, few tourists routinely search for ecolabels in product purchasing decisions. Numerous ecolabel schemes have been established or proposed, but many were very small or specialized, and few have prospered. Among the latter, however, there are some very solid examples of schemes 
which have been built slowly and now have strong recognition and endorsement by customers, industry, and government. Programs such as those run by Germany's Touristik Union International and the Ecotourism Association of Australia, and the Blue Flag label for European beaches and marinas, are well-established and are likely to become firmly entrenched features of environmental management and marketing in tourism.

By far the largest unknown is the resurgence of Green Globe in its new format as Green Globe 21. Because tourism is an international industry, international ecolabels will generally be more useful than localized ones. To have market value for tourism corporations, however, an ecolabel must be meaningful to consumers and host communities, including their land management and regulatory agencies. This requires details specific to particular areas and activities. Therefore, global schemes such as Green Globe must be customized to particular areas and activities. They also require rigorous and reliable independent audit. Green Globe 21 has promised these. It remains to be seen whether it will be able to fulfil its promise as an international sector-wide ecolabel meaningful to customers, companies, communities, and conservation organizations alike, and able to play a significant role in improving the environmental performance of the industry worldwide. It may get at most a couple of years' grace to prove how far it is capable and committed to delivering environmental as well as marketing benefits. Certainly its senior management seems dedicated, but the massive inertia of any global industry, particularly the innumerable small and medium enterprises and those in less environmentally concerned countries, should not be underestimated. If it can deliver on all its goals, Green Globe 21 has enormous potential, but it has already been subject to significant 
criticism by at least one well-respected conservation group (WWF-UK 2000), and it will face enormous difficulties in maintaining its vision. A parallel approach in another sector, the chemical industry's Responsible Care Program, has been subject to extensive criticism (Gunningham and Grabosky 1999).

As an instrument of consumer choice, ecolabels are a valuable environmental management tool in tourism. To be most effective, they should be integrated with public policy mechanisms such as environmental regulations and standards. They also need to be supported by guidelines and manuals for best practice, and by benchmarking and public reporting schemes for all aspects of environmental performance, including management, technologies, interpretation, and contributions to conservation.

To be useful and reliable, ecolabel schemes need effective assessment and audit procedures, and penalties for non-compliance, as well as clearly-defined admission or accreditation criteria. This information needs to be publicly available both to individual consumers and to companies considering joining the ecolabel scheme. Where an ecolabel uses a broad term such as sustainability, the practical criteria and processes used to decide whether or not a particular product can use the ecolabel, need to be clear and publicly defined. Another issue yet to be confronted seriously is the international trade implications of any formal scheme. Ecolabels have a particular meaning and context in international trade. In other industries, international trade agreements operate through domestic and international political processes to limit the ability of individual countries to improve environmental standards. The particular features of tourism, however, 
should enable it to adopt ecolabels without conflicting either with international trade agreements or domestic environmental legislation.

While most of the problems for tourism ecolabels are issues of technical detail and practical implementation, there is one broad question of definition which needs to be addressed before customers become confused. This is the distinction between the quality of the natural resources in a particular place, and the quality of environmental management by a particular company or in a particular tourism product. Australia's NEAP focuses on the latter; Europe'sBlue Flag on the former. Green Globe 21 now includes a certification category for entire destinations; but it is not fully clear whether this reflects quality, natural resources at the destinations concerned, or environmental management by tourism operators based there. Whatever the outcome, it seems highly probable that ecolabels will become increasingly important in tourism as in other industries. The steps being taken now to improve existing label schemes are hence of considerable interest and significance for both the environment and the tourism industry. 


\section{REFERENCES}

Basche, C.

1998 Being Green is your Business. Gold Coast: CRC Tourism and Tourism Council Australia.

British Airways

1999 Annual Environmental Report. London: British Airways.

British Holiday and Home Parks Association 2000 David Bellamy Conservation Awards. <www.ukparks.com/bellamy>. Viewed 5 February 2001.

Brown, L., G. Davis, E. Eiderstroem, K. Eisen, J. Kusz, J. Lynch, R. Rattray, S. Rhodes, R. Shimp, and A. Weismann

1997 Special Issue on Ecolabels. Forum for Applied Research and Public Policy 12:116-144.

Buckley, R. C.

1992 New United States Federal Trade Commission Guidelines for Ecolabeling and Green Advertising. Environmental and Planning Law Journal 9:479.

1994 A Framework for Ecotourism. Annals of Tourism Research 21:661-669.

1995 Accreditation—or No? Ecotraveler 2:9.

1996 Sustainable Tourism: Technical Issues and Information Needs. Annals of Tourism Research 23:925-928.

1997 Improving the Quality of EIA. In Environmental Methods Review, A. Porter and J. Fittipaldi, eds., pp. 41-49. Tampa: AEPI. 
1999 Green Globe 21. Presentation to WTTC/UNCSD Tourism Agenda 21, Asia-Pacific Region, Hong Kong, Green Globe 21. 2000 Green Guide to White Water. Gold Coast: CRC Tourism. 2001 Turnover and Trends in Tourism Ecolabels. In Tourism Ecolabels, X. Font and R. C. Buckley, eds., pp. 189-212. London: CABI.

Caribbean Alliance for Sustainable Tourism $2000<$ www.cha-cast.com>. Viewed 5 February 2001.

Commonwealth Department of Tourism

1994 National Ecotourism Strategy. Canberra: Commonwealth Department of Tourism.

Conservation Foundation

2000 The Conservation Foundation.

<www.conservationfoundation.co.uk>. Viewed 5 February 2001.

Department of Tourism, Small Business and Industry

1997 Queensland Ecotourism Plan. Brisbane: Department of Tourism, Small Business and Industry.

Deutscher Hotel-und Gaststattenverband. 2000 Welcome to the Home Page of the German Hospitality Industry. $<$ www.dehoga.de>. Viewed 5 February 2001.

Diamantis, D.

1998 Consumer Behaviour and Ecotourism Products. Annals of Tourism Research 25:515-518. 
Dudley, N., C. Eliott, and S. Stolton

1997 A Framework for Environmental Labeling. Environment 39: 1620, 42-45.

Ecotourism Association of Australia

2000 About NEAP. <www.ecotourism.org.au>. Viewed 5 February 2001.

Ecotourism Association of Australia and Australian Tour Operators Network

1999 National Ecotourism Accreditation Program (2nd ed.). Brisbane: EAA and ATON.

Europarc Federation

2000 The Europarc Federation. <www.europarc.org>. Viewed 5 February 2001.

European Golf Association Ecology Unit

2000 Committed to Green. <www.golfecology.com> Viewed 5 February 2001.

European Union

2000 European Union Home Page. <www.europa.eu.int>. Viewed 5 February 2001.

Federation des Parcs Naturels Regionaux de France 2000 Index of Les Gites. <www.parcs-naturelsregionaux.tm.fr/lesgites>. Viewed 5 February 2001.

Fennell, D. A. 
1999 Ecotourism: An Introduction. London: Routledge.

Foundation for Environmental Education in Europe

2000 Blue Flag Campaign. <www.blueflag.org>. Viewed 5 February 2001.

Green Globe 21

2000 Green Globe 21. <www.ggasiapacific.com.au>. Viewed 5 February 2001.

Green Seal

2000 Greening your Property. <www.greanseal.org>. Viewed 5 February 2001.

Grodsky, J.

1993 Certified Green: The Law and Future of Environmental Labeling. Yale Journal of Regulation 10:147-227.

Gunningham, N., and P. Grabosky

1999 Smart Regulation: Designing Environmental Policy. Oxford: Clarendon Press.

Hamele, J.

1996 The Book of Environmental Seals and Ecolabels: Environmental Awards in Tourism-An International Overview of Current Development. Berlin: Federal Ministry for Environment, Nature Conservation and Nuclear Safety.

Hemmelskamp, J., and K. Brockmann 
1997 Environmental Labels: The German "Blue Angel”. Futures 29:67-76.

Honey, M., and A. Rome

2000 Ecotourism and Sustainable Tourism Certification. Washington DC: Institute for Policy Studies.

\section{HORESTA}

2000 Welcome Page. <www.danishhotels.dk>. Viewed 5 February 2001.

\section{IHEI 1997}

Environmental Management for Hotels (2nd ed.). London: Butterworth-Heinemann.

Kleinwalser Tourismus

2000 Kleinwalsertal: Eine Welt fur Dich. <www.tiscover.com/kleinwalsertal>. Viewed 5 February 2001.

Mihalic, T.

1998 Ecological Labeling in Tourism. In Sustainable Tourism in Islands and Small States: Issues and Policies, L. Briguglio, B. Archer, J. Jafari and G. Wall, eds., pp. 195-205. London: Pinter.

Morris, L. A., M. Hastak, and M. B. Mazis

1995 Consumer Comprehension of Environmental Advertising and Labeling Claims. Journal of Consumer Affairs 29:328-350.

National Audubon Society, Inc. 2000 Audubon. <www.audubon.org>. Viewed 5 February 2001. 
National Outdoor Leadership School

1997a Leave No Trace Outdoor Skills and Ethics: Backcountry Horse Use. Lander WY: NOLS.

1997b Leave No Trace Outdoor Skills and Ethics: Tropical Rainforests. Lander WY: NOLS.

Pacific Asia Travel Association

2000 PATA Haome page. <www.pata.org>. Viewed 5 February 2001.

Stabler, M. J., ed.

1997 Tourism and Sustainability: Principles to Practice. New York: CAB International.

Swarbrooke, J.

1999 Sustainable Tourism Management. New York: CAB International.

Tidy Britain Group

2000 The Seaside Awards. <www.tidybritain.org.uk/psea>. Viewed 5 February 2001.

Tourism and Environment Forum

2000 Tourism and the Environment: Sustaining Scotland's Natural Advantage. <www.visitscotland.com>. Viewed 5 February 2001.

TUI Group

2000 TUI Group Environmental Management. <www.tui-umwelt.de>. Viewed 5 February 2001. 
Tourism Authority of Thailand

2000 Home page. <www.tat.or.th>. Viewed 5 February 2001.

United Nations Environment Program

1995 Environmental Codes of Conduct for Tourism Industry and Environmental Technical Report No. 29. Paris: UNEP.

1998 Ecolabels in the Tourism Industry. Paris: UNEP.

United Nations Environment Program, World Tourism Organization, and Foundation for Environmental Education in Europe 1996 Awards for Improving the Coastal Environment: The Example of the Blue Flag. Paris: UNEP.

Vinot, $\mathrm{K}$.

1999 Can You Believe It? Verification of Environmental Reports. Groundwork 2(3):21-23.

Von Mirbach, M.

1999 Demanding Good Wood. In Voluntary Initiatives: The New Politics of Corporate Greening, R. B. Gibson, ed., pp. 211-226. Ontario: Broadview Press.

Weaver, D.

1998 Ecotourism in the Less Developed World. Oxford: CAB International.

1999 Indicators for Sustainable Tourism. CRC Tourism Report 1999/1. Gold Coast: CRC Tourism.

2000 Encyclopaedia of Ecotourism. Oxford: CAB International. 
1996 What Tourism Managers Need to Know: A Practical Guide to the Development and Use of Indicators of Sustainable Tourism. Madrid: WTO.

1998a Ecotourism Now One-Fifth of Market. World Tourism Organization News 1:6.

1998b Guide for Local Authorities on Developing Sustainable Tourism. Madrid: WTO.

World Wide Fund for Nature

2000 WWF Global Network.

$<$ www.panda.org/resources/programs/europe>. Viewed 5 February 2001.

WWF-UK

2000 Tourism Certification: An Analysis of Green Globe 21 and Other Tourism Certification Programmes. London: Synergy. 